\title{
Covid-19 Vaccination: Rights or Obligations?
}

\author{
Vica Jillyan Edsti Saija \\ Faculty of Law Pattimura University, Ambon, Indonesia \\ E-mail:vicasaija@gmail.com
}

\begin{tabular}{l}
\hline Article Info \\
\hline Keywords: \\
Covid-19 \\
Vaccination; Human \\
Rights; Human \\
Obligations. \\
\\
DOI: \\
10.47268/sasi.v27i4.683 \\
\hline
\end{tabular}

Abstract
In responding to the pandemic due to the coronavirus, the Indonesian
government requires the public to carry out vaccinations in order to prevent
the spread of the coronavirus and establish herd immunity. This instruction
contradicts that health is a form of human right that cannot be enforced.
Therefore, this paper wants to examine whether COVID-19 vaccination in
the midst of an pandemic situation is a form of human right or obligation.
The research method used in this paper is a normative method, and the
results of this paper indicate that the covid-19 vaccine during an pandemic
period can be categorized as a form of human obligation for everyone
based on the obligation to respect the human rights of others as stated in
the State Constitution. The Republic of Indonesia in 1945.

\section{A. INTRODUCTION}

Corona Virus Disease-19 (COVID-19) has a significant impact on all aspects of human life in the world, especially in Indonesia which is very large in area and has a large population (around 267 million people) with different kinds of professions ${ }^{1}$, The Covid-19 pandemic on global economic developments has an influence not only on the world of economy and investment but also correlates with aspects of legal development. ${ }^{2}$

Article $28 \mathrm{H}$ paragraph 1 of the 1945 Constitution of the Republic of Indonesia states that "everyone has the right to live in physical and spiritual prosperity, to have a place to live, and to have a good and healthy living environment and the right to health services". Further regulation regarding Health in Indonesia can be found in Law Number 36 Year 2009 concerning Health. Article 1 of Law Number 36 the Year 2009 states that "health is a healthy state, both physically, mentally, spiritually and socially that allows everyone to live socially and economically productive". Even in this Law, it is also stated in Article 4 that everyone has the right to health. Likewise, Article 9 of Law Number 39 of 1999 concerning Human Rights regulates a person's right to life.

The government's efforts to maintain public safety ${ }^{3}$, the government is responsible for

1 Kunarso, K., \& Sumaryanto, A. D. (2020). Eksistensi Perjanjian Ditengah Pandemi Covid-19. Batulis Civil Law Review, 1(1), 33-46.

2 Saija, R., \& Sudiarawan, K. A. (2021). Perlindungan Hukum Bagi Perusahaan Debitur Pailit dalam Menghadapi Pandemi Covid 19. Batulis Civil Law Review, 2(1), 66-77.

3 Taun, T., \& Nugraha, A. (2020). Penerapan Hukum dalam Pemutusan Hubungan Kerja dan Kebijakan 
protecting human rights, as stated in Article 28I paragraph (4) of the 1945 Constitution of the Republic of Indonesia which states that the protection, promotion, enforcement and fulfillment of human rights are the responsibility of the state, especially the government. Therefore, the Indonesian government obliges its citizens to vaccinate against Covid-19, due to the SARSCoV-2 Virus which was later known as Covid-19 or the coronavirus.

The spread of hoaxes, the lack of health education about COVID-19 and its vaccinations have made people reluctant to participate in vaccinations, in addition to the growing assumption that vaccination as a person's right to health is a form of human right that does not need to be implemented if the person concerned does not want it. Based on the description above, the author tries to examine further whether vaccination during this epidemic is a person's right or obligation. This writing uses a normative method, with an approach through legislation and legal concepts.

\section{B. RESULTS AND DISCUSSION}

In human life, there are various ways to maintain health, one of which is by doing work. According to the Regulation of the Minister of Health Number 12 of 2017 concerning the Implementation of Immunization, exercise is an effort to actively generate/increase a person's immunity to a disease so that if one day they are exposed to the disease, they will not get sick or only experience mild illness. Immunizations are given to both children and adults, this is done in order to increase endurance and immunity. In the use of what is called a vaccine, according to the Regulation of the Minister of Health Number 12 of 2017, "vaccine is a biological product that contains antigens in the form of dead or living microorganisms that are attenuated, still intact or parts of it, or in the form of toxin microorganisms that have been processed into toxoids. or recombinant protein, which is added with other substances, which when given to a person will cause active specific immunity against certain diseases.

At the end of 2019, the world was shocked by the outbreak of COVID-19 in Wuhan, China, which has spread throughout the world, including Indonesia. The spread of this virus develops at several levels, from an endemic, epidemic, pandemic, and endemic. According to an article on the Airlangga University Faculty of Nursing website ${ }^{4}$ In the spread of a disease, there are several levels that occur. Endemic diseases develop into epidemics. If the spread extends throughout the world, then it is called a pandemic. The World Health Organization (WHO) declared Covid-19 a global pandemic on March 11, 2020. However, one year has passed, the spread of Covid-19 has not stopped. The latest statement from WHO is that Covid-19 is an endemic disease. Therefore, this disease will continue to exist and not completely disappear.

The extraordinary spread of Covid-19 marked by the number of cases and/or the number of deaths has increased and spread across regions and across countries and has an impact on political, social, cultural, defense and security aspects, as well as reasons for welfare in Indonesia. as contained in the Preamble to the Presidential Decree of the Republic of Indonesia Number 11 of 2020, issued by President Joko Widodo. Thus, Indonesia's status facing Covid19 is a health emergency.

WHO in 2020 declared Covid-19 as a global pandemic and the Government of Indonesia through the President issued Presidential Decree No. 12 of 2020 concerning the Determination of Non-Natural Disasters for the Spread of Corona Virus Disease 2019 (Covid-19) as a National Disaster. Furthermore, the Presidential Regulation of the Republic of Indonesia Number 99 of 2020 concerning Vaccine Procurement and Vaccination Implementation in the Context of Overcoming the Covid-19 Pandemic was stipulated. One of the reasons for the issuance of this $\begin{gathered}\text { Bank Terhadap Debitur yang Terdampak Pandemi Covid-19. Batulis Civil Law Review, 1(1), 24-32. } \\ 4\end{gathered}$ https://ners.unair.ac.id/site/index.php/news-fkp-unair/30-lihat/808-bedanya-endemi-epidemi-dan-
pandemi, March,18 2021

431 |S ASI Volume 27 Issue 4, October-December 2021 
regulation, as contained in its preamble, is in the context of controlling the Covid-19 outbreak/pandemic and maintaining public health, so it is necessary to accelerate and procure the Covid-19 vaccine and the implementation of the Covid-19 vaccination in accordance with the availability and needs determined by the government. Government The issuance of this regulation realizes the responsibility of the state as stated in Article 28I paragraph (4) of the 1945 Constitution of the Republic of Indonesia, which states that the protection, promotion, enforcement, and fulfillment of human rights are the responsibility of the state, especially the government.

As mentioned above regarding the regulation of human rights, the right to health can be based on Article 28H paragraph (1) of the 1945 Constitution of the Republic of Indonesia, with the regulation on the right to health, the consequence is that the government has an obligation to fulfill these rights, and this action is carried out by the government to its citizens free of charge. Thus, it can be concluded that the procurement and implementation is a form of state responsibility in fulfilling the services of the rights of its citizens, as well as a form of government.

When the government implements a vaccination program, there are pros and cons among people who want to be vaccinated and those who do not want to be vaccinated. Based on the Indonesian Political Indicators Survey, around $41 \%$ of the population refused to be vaccinated on the grounds that the party refused the vaccine $(41 \%)$ for the following reasons: ${ }^{5}$

1) feel that the vaccine has side effects that have not been found or are not safe (54\%)

2) vaccines are not effective (27\%)

3) thinks he does not need the vaccine because he feels his body is healthy $(23.8 \%)$

4) think that the vaccine is not free $(17.3 \%)$

5) vaccines may not be halal $(10.4 \%)$

6) no need to be vaccinated, because there are many people who will get vaccinated $(5.9 \%)$

7) lain-lain $(11 \%)$.

The data above shows that the Indonesian people have not fully trusted vaccines as a form of prevention against diseases, in this case, the coronavirus. Even though the benefits of vaccination are important for the human body, as explained on the website of the Bali Provincial Health Office ${ }^{6}$ that vaccination is the administration of vaccines (antigens) that can stimulate the formation of immunity (antibodies) of the immune system in the body. Vaccination is a very reliable primary prevention effort to prevent diseases that can be prevented by vaccination. With the correct vaccination procedure, it is hoped that optimal immunity, safe injections and minimal Post Immunization Adverse Events (AEFI) will be obtained. that vaccination is the administration of vaccines (antigens) that can stimulate the formation of immunity (antibodies) of the immune system in the body. Vaccination is a very reliable primary prevention effort to prevent diseases that can be prevented by vaccination. With the correct vaccination procedure, it is hoped that optimal immunity, safe injections, and minimal Post Immunization Adverse Events (AEFI) will be obtained.

The immune system against a disease can be formed naturally when a person is infected with a virus or bacteria that causes it. However, coronavirus infection has a high risk of death and transmission. Therefore, we need another way to form the immune system, namely vaccination. The Covid-19 vaccination is carried out after certainty of its safety and efficacy, is an effort to reduce morbidity and mortality and encourage the formation of herd immunity. In addition, the Covid-19 vaccination aims to protect and strengthen the health system as a whole,

5 Srihandriatmo Malau, Menurut Survei, Ini Alasan Utama 41 Persen Orang Indonesia Tidak Mau Divaksin Covid-19, https://www.tribunnews.com/corona/2021/02/21/menurut-survei-ini-alasan-utama-41-persen-orangindonesia-tidak-mau-divaksin-covid-19?page=2, 21 February 2021.

${ }^{6} \mathrm{https}$ //www.diskes.baliprov.go.id/yuk-kenali-lebih-jauh-vaksinasi-covid-19/, 8 March 2021 
as well as maintain productivity and reduce the social and economic impact of society. ${ }^{7}$

From the explanation above, it can be seen that the vaccine will make a person's body recognize the bacteria/virus that causes certain diseases (in this case the corona) so that when exposed to these bacteria/viruses they will become more resistant. High and even coverage of immunization will form herd immunity so that it can prevent transmission and severity of a disease. Here can be seen the relationship between vaccines, immunization, and herd immunity.

In addition, important information about vaccines as mentioned above, of course, is known by the whole community, because the lack of education about vaccines will affect the level of vaccination awareness, this is exacerbated by the development of vaccines, which are then trusted by the public. According to the Spokesperson for the Ministry of Communication and Information, Dedy Permadi ${ }^{8}$, confused about finding 105 hoax issues related to the Covid19 vaccine until February 10, 2021, there were 417 posts of hoax vaccines that had been taken down. The most spread was on Facebook with 314 posts. The rest is on Instagram, Twitter, YouTube, and TikTok. The solution for the spread of hoaxes, apart from deleting these posts, is another solution, namely through socialization that can be done in every media, both print and online, and directly provide explanations to the public. The role of government at lower levels, such as RT/RW or village, can be utilized to interact with the community in their respective environments together with the Health Office.

The opinion that is built around vaccines is not just a hoax, but there is an opinion that the right to health as written in the 1945 Constitution of the Republic of Indonesia is a human right of every person, so it should not be forced if the person does not want it. According to Satjipto Raharjo 9 a person's right as a power conferred by law, with a view to protecting that person's interests. This right is the allocation of certain powers to people who act in the context of that interest. Thus, the right is given to protect a person or his interests. Furthermore, according to Sudikno Mertokusumo ${ }^{10}$, These rights provide individual enjoyment and freedom in carrying out their obligations, obligations, and so that an active impact arises in the legal relationship, namely rights. Thus, what is always heard so far is only human rights, while human obligations are never mentioned.

Human rights according to C. De Rover ${ }^{11}$ is a legal right that every human being has. This right is universal and belongs to everyone, rich or poor, male or female. The regulation of human rights in Indonesian legal instruments can be found in Article 1 of Law Number 39 of 1999, providing a not much different definition, namely that human rights are a set of rights that are inherent in the nature and existence of humans as creatures of God Almighty and are gifts. Him who must be respected, upheld and protected by the state, law, government and everyone for the sake of honor and protection of human dignity.

From the various definitions given, some basic characteristics or principles that underlie human rights can be summarized, namely ${ }^{12}$ :

1) Attached to humans, hams are attached to humans. He has it because of his human dignity

2) Universal, ham applies to everyone

7 Ibid

8 Haryanti Puspa Sari, Kemenkominfo Temukan 105 Isu Hoaks Terkait Vaksin Covid-19, https://nasional.kompas.com/read/2021/02/10/19545431/kemenkominfo-temukan-105-isu-hoaks-terkait-vaksincovid-19, 10 February 2021

9 Ali, A. (2011). Menguak Tabir Hukum, Cetakan ke-3, Bogor: Ghalia Indonesia, p. 178.

10 Mertokusumo, S. (2010). Mengenal Hukum Suatu Pengantar, Yogyakarta: Cahaya Atma Pustaka, p. 51.

11 Renggong, R. (2014). Hukum Acara Pidana Memahami Perlindungan HAM dalam Proses Penahanan di Indonesia. Edisi Revisi, Jakarta: Prenada Media Group, p. 23.

12 Prasetyo, E. (2008). Buku Ajar Hak Asasi Manusia, Yogyakarta: Edisi Guru SMU, Pusat Studi Hak Asasi Manusia Universitas Islam Indonesia (PUSHAM UII), p. 3-4.

433 |S ASI Volume 27 Issue 4, October - December 2021 
3) The basis, forms the basis for existence as a human being

4) Equal, everyone has the same rights

5) Inseparable, human rights cannot be found, issued or handed over, nor can they be restricted unless stipulated by law

6) Indivisible, based on principles with human dignity, indivisible, all interrelated, indivisible

7) Not absolute, human rights can be sacrificed if there are other social interests that are more important, in special situations, in a limited time and with limited purposes that are really deemed necessary, except for non-derogable rights.

8) Minimum protection, human rights provide moral recognition of experience and all human beings and recognition that everyone needs to be given the opportunity to develop themselves to the fullest.

9) State obligations, human rights are legal recognition of state obligations to ensure that these rights are protected and can be fulfilled for all citizens.

Based on this principle, the authors conducted a study on the opinion that vaccines are rights that can be exercised or not by the owner of the rights as he wishes. If vaccination is a form of human rights then of course it is inherent in humans, because of their dignity as a human being. Vaccination is owned by everyone because it is universal. The basis for considering the existence of a human being, is equal because anyone who is vaccinated has the same rights. As a form of human rights, vaccination cannot be separated from humans themselves unless otherwise stipulated by law. Vaccination as an effort to prevent disease cannot be separated from the right to life of a person or many people in an endemic situation.

One of the principles of human rights that are not absolute, then a person's human rights can be sacrificed if there are other social interests that are more important, in special situations, in a limited time and with limited goals that are really deemed necessary, this principle is in line with the situation and conditions, faced by the whole world due to the Covid-19 endemic, so that a person's right not to want to be vaccinated for reasons that cannot be medically justified due to his body (age, disease, and other conditions), can be set aside in the interest of the rights of many people. The following explanation with the benefits of the vaccine mentioned above is an effort to reduce mortality and encourage the formation of group immunity. This is in accordance with Article 28J paragraph (1) of the 1945 Constitution which clearly mandates that everyone is obliged to respect the human rights of others, so that it is everyone's obligation to respect the health rights of others, to form group immunity so as not to transmit disease to others. More according to Sudikno Mertokusumo ${ }^{13}$ Rights and obligations are a collection of rules or regulations, which are a balance of power in the form of individual rights on the one hand and obligations on the other. If there are rights, there are obligations. These rights and obligations are obligations to a person by law. Thus, a person's human rights must be in accordance with his obligations, in the human rights of the obligation to respect the rights of others as regulated in the 1945 Constitution.

Furthermore, protection, vaccination as a form of moral recognition of the dignity and of all human beings in obtaining their right to health. Finally, as a state obligation, in accordance with the explanations above, it can be seen that the covid-19 vaccination, carried out by the government, is an implementation of the government's obligation to ensure that human health rights are protected and can be fulfilled. The following are some of the responsibilities of the state through legal instruments that apply in Indonesia, which are related to this issue, namely Article 34 paragraph (1) of the 1945 Constitution stipulating health services as the responsibility of the state, Law 36 of 2009 Article 15, namely the Government is responsible for the availability of health services, environment, arrangement, health facilities both physical, and social for the community to achieve the highest degree of health, and Article 16 which states

13 Mertokusumo, Sudikno. Op. Cit, p. 52

434 | S A S I Volume 27 Issue 4, October- December 2021 
that the Government is responsible for the availability of resources in the health sector that is fair and equitable for the entire community to obtain the highest degree of health. Article 8 of Law Number 39 of 1999, namely the protection, promotion, enforcement and fulfillment of human rights are primarily the responsibility of the Government. By providing free treatment for patients infected with Covid-19, providing and implementing Covid-19 vaccinations, and other measures to maintain the health of its people, it has demonstrated the state's obligation to fulfill and protect the human rights of its citizens. In addition, in this endemic situation, government actions that require vaccination can be based on the legal principle of salus animarum suprema lex (safety of souls is the main law) or salus populis suprema lex (safety of the people is the highest law).

\section{CONCLUSION}

The relationship between vaccines, exercise, and herd immunity, makes vaccination a right for everyone's health, not only for the benefit of one person but also for many people considering COVID-19 is an infectious disease. So that making the rights of others for the common good become the obligation of everyone, the implementation of work must be balanced with human obligations. Thus, the principle of human rights is not absolute, that a person's human rights can be sacrificed if there are other social interests that are more important, in special situations, within a limited time and with a limited purpose that is really deemed necessary, furthermore Article 28J paragraph (1) The 1945 Constitution states that everyone is obliged to respect the human rights of others, and the legal principle of salus animarum suprema lex or salus populis suprema lex can be used as a basis for categorizing vaccination not only as a human right but as an obligation for everyone.

\section{REFERENCES}

\section{Journal}

[1] Kunarso, K., \& Sumaryanto, A. D. (2020). Eksistensi Perjanjian Ditengah Pandemi Covid19. Batulis Civil Law Review, 1(1), 33-46.

[2] Saija, R., \& Sudiarawan, K. A. (2021). Perlindungan Hukum Bagi Perusahaan Debitur Pailit dalam Menghadapi Pandemi Covid 19. Batulis Civil Law Review, 2(1), 66-77.

[3] Taun, T., \& Nugraha, A. (2020). Penerapan Hukum dalam Pemutusan Hubungan Kerja dan Kebijakan Bank Terhadap Debitur yang Terdampak Pandemi Covid-19. Batulis Civil Law Review, 1(1), 24-32.

\section{Books}

[4] Ali, A. (2011). Menguak Tabir Hukum, Cetakan ke-3, Bogor: Ghalia Indonesia.

[5] Mertokusumo, S. (2010). Mengenal Hukum Suatu Pengantar, Yogyakarta: Cahaya Atma Pustaka.

[6] Prasetyo, E. (2008). Buku Ajar Hak Asasi Manusia, Yogyakarta: Edisi Guru SMU, Pusat Studi Hak Asasi Manusia Universitas Islam Indonesia (PUSHAM UII).

[7] Renggong, R. (2014). Hukum Acara Pidana Memahami Perlindungan HAM dalam Proses Penahanan di Indonesia. Edisi Revisi, Jakarta: Prenada Media Group.

\section{Online/World Wide Web, Thesis}

[8] https://ners.unair.ac.id/site/index.php/news-fkp-unair/30-lihat/808-bedanya-endemiepidemi-dan-pandemi.

[9] https://www.diskes.baliprov.go.id/yuk-kenali-lebih-jauh-vaksinasi-covid-19/.

[10] Haryanti Puspa Sari, Kemenkominfo Temukan 105 Isu Hoaks Terkait Vaksin Covid-19, https://nasional.kompas.com/read/2021/02/10/19545431/kemenkominfo-temukan-105- 
isu-hoaks-terkait-vaksin-covid-19.

[11] Srihandriatmo Malau, Menurut Survei, Ini Alasan Utama 41 Persen Orang Indonesia Tidak Mau Divaksin Covid-19, https://www.tribunnews.com/corona/2021/02/21/menurutsurvei-ini-alasan-utama-41-persen-orang-indonesia-tidak-mau-divaksin-covid-19?page $=2$. 